\section{ScienceDirect}

Procedia - Social and Behavioral Sciences 00 (2016) 000-000

\section{Procedia}

Social and Behavioral Sciences

www.elsevier.com/locate/procedia

The 4th International Conference on Islam and Higher Education (ICIHE-2016)

\title{
DELAPAN CARA PEMBINAAN MOTIVASI DI KALANGAN PENDIDIK
}

\author{
Syafrimen $^{\mathrm{a}}$, Noriah Mohd. Ishak ${ }^{\mathrm{b}}$, Nova Erlina ${ }^{\mathrm{c}}$, Titik Rahayu ${ }^{\mathrm{d}}$ * \\ ${ }^{\mathrm{a}, \mathrm{c}, \mathrm{d}}$ Universitas Islam Negeri Raden Intan Lampung, Indonesia \\ ${ }^{\mathrm{b}}$ Pusat PERMATA pintar ${ }^{\mathrm{tm}}$ Negara National University of Malaysia \\ 43600 UKM, Bangi Selangor, Malaysia
}

\begin{abstract}
Pembinaan motivasi sangat perlu bagi pendidik untuk membentuk pribadi yang professional dalam dunia pendidikan. Motivasi merupakan penopang bagi pendidik, karena pendidik merupakan figur utama umtuk mencapai kesuksesan belajar. Penelitian ini bertujuan untuk melihat cara pembinaan motivasi di kalangan pendidik Fakultas Tarbiyah dan keguruan Universitas Islam Negeri (UIN) Raden Intan Lampung, Indonesia. Penelitian dijalankan menggunakan pendekatan kualitatif (case multi-site exsploratory case study), melibatkan 7 orang pendidik yang berpengalaman, subjek dipilih melalui teknik "porposive sampling". Data dikumpulkan melalui wawancara secara mendalam (indepth interview), dan dianalisis secara tematik berbantukan software NVIVO 10. Hasil penelitian menunjukkan terdapat delapan komponen dalam pembinaan motivasi, yaitu (i) usaha secara maksimal, (ii) melihat tantangan sebagai peluang, (iii) perencanaaan, (iv) disiplin dan konsisten, (v) belajar dari keberhasilan orang lain, (vi) belajar dari kegagalan diri sendiri, (vii) tujuan harus jelas, dan (viii) amanah. Selanjutnya, hasil penelitian dibincangkan secara mendalam dengan berbagai hasil penelitian sebelumnya.
\end{abstract}

(C) 2016 The Authors. Published by Elsevier Ltd.

Peer-review under responsibility of the Kolej Yayasan Pahang, Malaysia.

Keywords: Pembinaan Motivasi, Pendidik;

\footnotetext{
* Corresponding author. Tel.: +6281374576227;

E-mail address: syafrimen@ radenintan.ac.id
} 


\section{Pengenalan}

Kualifikasi pendidik sangat penting dalam ruang lingkup sekolah (Erdem, 2014b). Pendidik memiliki tanggungjawab yang tinggi, sehingga pendidik harus memiliki motivasi dalam mensukseskan tugas tersebut (Goleman, 2001; Rohaty, 2002). Motivasi didefinisikan sebagai suatu dorongan atau inspirasi seseorang dalam melakukan kegiatan yang mengarah pada tujuan (Roussel, 2000). Untuk melaksanakan tugas mendidik dengan baik, pendidik tidak cukup hanya memiliki kemampuan akademik dan keterampilan mengajar, namun mereka memerlukan keterampilan psikologis "motivasi" untuk mengantarkan siswa ke arah yang lebih baik (M. I. Noriah, Zuria,M, Siti Rahayah, A. dan Manisah M.A, 2003) Sememangnya, pemahaman tentang motivasi dan latihan motivasi sangat perlu diberikan kepada pendidik-pendidik pada waktu proses persiapan melahirkan pendidikpendidik tersebut (Skovholt, 2000). Demikian juga halnya dengan hasil-hasil penelitian di Negara serumpun yang juga mendapati tentang kepentingan motivasi bagi pendidik (Ashiba, 2004).

Keterampilan dan keperibadian pendidik dapat diperoleh melalui latihan dan pengalaman sewaktu menjalani proses pendidikan (Ibrahim, 2002), sehingga mereka dapat memenej proses pembelajaran dengan baik ketika melaksanakan tugas di sekolah. Lulusan terbaik dari universitas terkenal belum menjamin bagi pendidik untuk memiliki keterampilan mendidik yang baik, namun mereka perlu dengan berbagai informasi dan keterampilan baru untuk menyesuaikan diri dengan perkembangan dan kebutuhan pendidikan terkini (Sani, 2001). Sikap positif pendidik terhadap pengajaran sangat penting demi kemajuan pendidikan (Leithwood, 2008). Menurut (Bogler, 2001) kepuasan kerja seorang pendidik sangat penting dalam hal retensi pendidik, selain itu terkait dengan pemberdayaan pendidik, iklim sekolah, kualitas lingkungan kerja, dan prestasi siswa. Untuk mewujudkan hal tersebut pendidik perlu memiliki motivasi sehingga pendidik dapat bekerja dengan hati, untuk itu pendidik perlu mengikuti pembinaan motivasi. Motivasi adalah proses internal, personal, proses sukarela dan tidak memaksa, serta mengarahkan upaya intelektual dan mental (Seebaluck, 2013). Menurut (Rich, 2010) motivasi sangat penting untuk mencapai keberhasilan dalam suatu organisasi. motivasi pendidik serius dapat mempengaruhi kemajuan sistem pendidikan (Finnigan, 2010; Hopkins, 2012).

Hasil penelitian di Thailand menunjukkan bahwa terdapat berbagai masalah terkait profesional pendidik (Sarojn Pasathang, 2016). Pendidik-pendidik banyak memiliki motivasi dan kerja rendah (Antoniou, 2000). Hal tersebut ditunjukkan pendidik dalam mengajar yang masih kurang efisien, sering membolos, tidak memiliki motivasi untuk bekerja, dan tidak memiliki kompetensi dalam bidang pengajaran (Education, 2010a, 2010b, 2010c). Demikian juga dengan hasil penelitian (M. I. Noriah, dan Aliza, A, 2002a), bahwa pendidik bukan saja memiliki motivasi kerja yang rendah, namun permasalahan terhadap kemurungan dan berbagai permasalahan psikologis. Padahal menurut (Schater, 2011), motivasi dapat dijadikan sebagai pendorong, pengontrol, dan memelihara perilaku tertentu yang diarahkan pada tujuan. Diperkuat oleh (Mitchell, 1997), bahwa motivasi dapat menjelaskan intensitas, arah, dan ketekunan individu dalam mencapai tujuannya. Hampir senada pada penelitian (Robbins, 2008), bahwa terdapat tiga elemen utama dalam motivasi, yaitu intensitas, arah, dan ketekunan. Sementara (Goleman, 1999) menyatakan bahwa motivasi merupakan penggunaan bisikan hati untuk menggerakan dan mengarahkan seseorang dalam mencapai suatu tujuan. Selain itu, motivasi sebagai salah satu domain (self competence) dalam konsep kecerdasan emosi (Goleman, 1999).

Selanjutnya, studi penelitian pada masyarakat Arab Israel tentang motivasi pendidik masih sangat minim dilakukan (Budden, 2009; Eyal, 2010; Rich, 2010; Seebaluck, 2013). Hal tersebut dipengaruhi tiga faktor utama, yaitu kesulitan dari budaya Arab, sekolah, negara dan kebijakan pemerintah daerah (Massry-Herzllah, 2016). Padahal motivasi pendidik sangat penting bukan hanya karena implikasinya bagi pribadi dan pengembangan profesional tetapi juga untuk meningkatkan kualitas pengajaran dan positif mempengaruhi motivasi belajar peserta didik, keberhasilan dan kemajuan akademis (Budden, 2009; Finnigan, 2010; Nir, 2014). Hal senada pada penelitian (Umaña-Taylor, 2015), sememangnya orang tua dan pendidik dapat menjadi pertimbangan penting berkaitan dengan motivasi akademik. Hal ini karena pendidik memberikan pengaruh prestasi akademik yang lebih tinggi, lebih jauh, dan lebih kuat dalam memberi dukungan akademik (Chen, 2008). 
Pencapaian tujuan yang diinginkan dalam pendidikan, pendidik harus cukup termotivasi dalam hal profesionaliti diri pribadi, suasana hati dan sikap terhadap profesi yang tinggi, serta motivasi yang stabil (Erdem, 2014a). Hal tersebut menjadi syarat bagi pendidik untuk membimbing peserta didik dalam fasilitasi pembelajaran, untuk menyediakan interaksi sosial dan mental dalam lingkungan belajar dan memotivasi mereka dalam keberhasilan akademis, yang bertujuan mengintegrasikan peserta didik secara aktif dalam proses pembelajaran (İlter, 2013). Sememangnya motivasi dapat dibina (V. H. Dulewicz, M, 2004). Hal tersebut terlihat pada penelitian (V. a. H. Dulewicz, M, 2000) bahwa kompetensi motivasi tersebut (dorongan untuk berhasil, komitmen, inisiatif dan optimis) secara berangsur dapat dikembangkan. Diperkuat oleh (Ginanjar, 2005), bahwa seseorang perlu melakukan latihan secara berkesinambungan (continuosly improvement) sehingga membentuk satu keperibadian yang kokoh. Selanjutnya, motivasi secara langsung mempengaruhi kinerja pendidik yang pada akhirnya dapat mempengaruhi keberhasilan suatu organisasi (Claudia, 2014).

\section{Metodologi}

Penelitian ini dijalankan menggunakan pendekatan kualitatif, dengan jenis penelitian studi kasus (case study research design) yaitu multi-case multi-site exploratory case study (Yin, 2008, 2013). Penelitian studi kasus merupakan jenis penelitian yang cukup komprehensif dengan menggabungkan berbagai cara dalam mengumpulkan dan menganalisis data (Yin, 2013). Penggunaan pendekatan studi kasus tersebut membolehkan peneliti untuk mendapatkan berbagai informasi secara mendalam berkaitan dengan permasalahan yang diteliti (Creswell, 2007, 2014, 2015; Wiersma, 2000; Yin, 1993, 2008, 2013). Data dikumpulkan melalui wawancara secara mendalam (indepth interview), dengan melibatkan 7 orang pakar yang dianggap cukup memberikan data. Teknik "porposive sampling" termasuk ke dalam nonprobality sampling yaitu pengambilan subjek kajian bergantung kepada peneliti melihat subjek tersebut. Data dianalisis secara tematik berbantukan software NVIVO 10, yaitu software analisis data yang dirancang khusus untuk menganalisis data kualitatif.

\section{Hasil Penelitian}

Hasil penelitian menunjukkan bahwa, terdapat delapan komponen penting dalam pembinaan motivasi, yaitu (i) usaha secara maksimal, (ii) melihat tantangan sebagai peluang, (iii) perencanaaan, (iv) disiplin dan konsisten, (v) belajar dari keberhasilan orang lain, (vi) belajar dari kegagalan diri sendiri, (vii) tujuan harus jelas, dan (viii) amanah. Pengalaman dan pandangan tentang masing-masing komponen dapat dilihat pada gambar 1 berikut: 


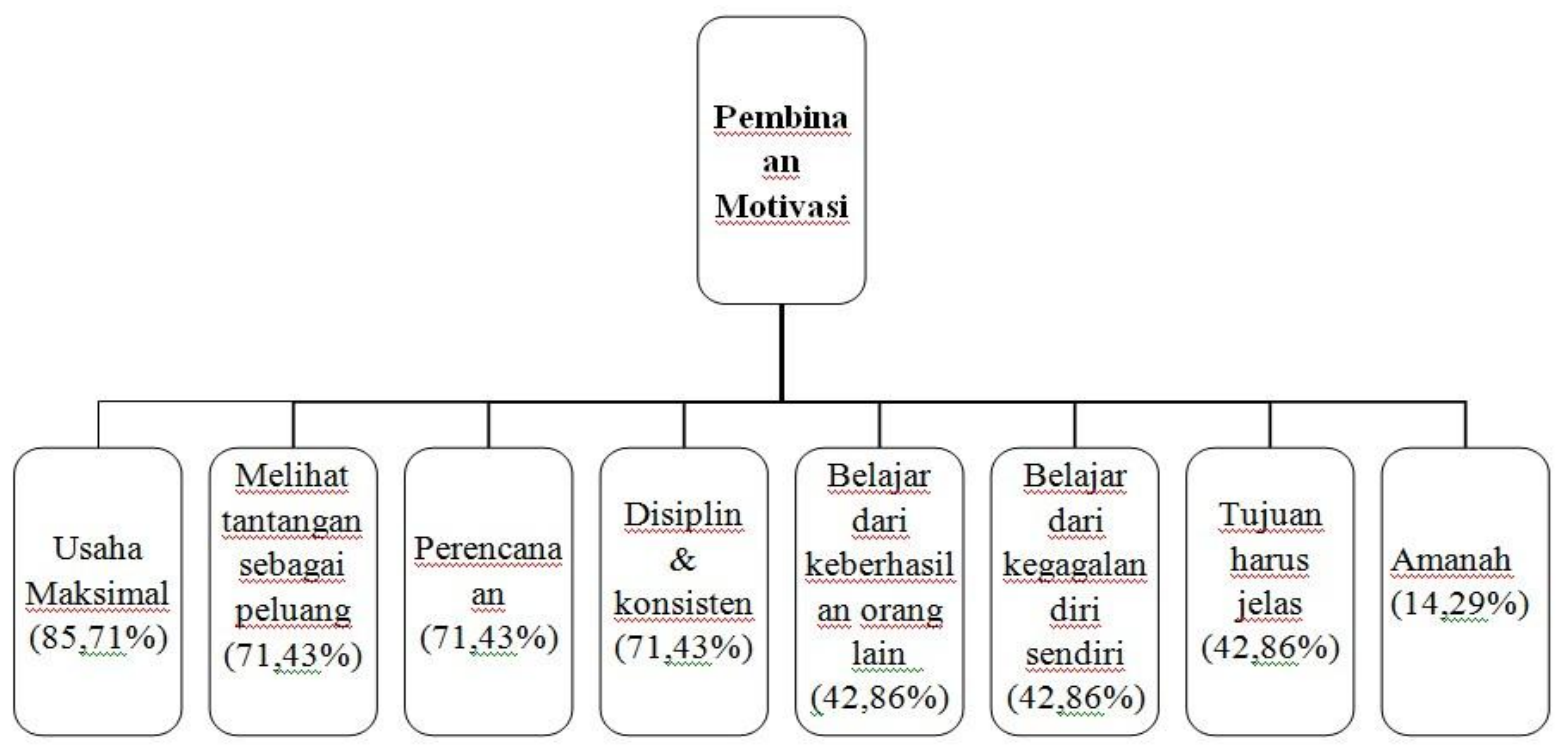

\section{Gambar 1 : Pengalaman subjek dalam pembinaan motivasi}

Berdasarkan gambar di atas, bahwa parsentase tertinggi diperoleh pada komponen berusaha secara maksimal $(85,71 \%)$, melihat tantangan sebagai peluang $(71,43 \%)$, perencanaan $(71,43 \%)$, disiplin dan konsisten $(71,43 \%)$, belajar dari keberhasilan orang lain (42,86\%), belajar dari kegagalan diri sendiri $(42,86 \%)$, tujuan harus jelas $(42,86 \%)$ dan amanah $(14,29 \%)$. Berikut beberapa contoh petikan-petikan wawancara beberapa pakar dalam pembinaan motivasi:

TBI3 : ... sesuatu yang baik itu perlu diusahakan... pokok yang baik itu perlu disiram dengan air, letak baja kan. Macam itu juga saya rasa dengan diri manusia ini, untuk menjadi yang terbaik kita perlu berusaha dan kita perlu ada macam saya kata tadilah, kita tidak boleh komplesen Melihat Tantangan sebagai Peluang

FG1 : Sebelum itu saya pergi ke SK yang teruk yang tidak ada apa-apa, pegawai tidak ada, kerani tidak ada. Jadi sayalah yang jadi kerani, PK koko, PKHEM, PK 1 dan guru besar. Jadi kerja saya betul-betul mentadbir sekolah termasuk gaji guru-guru. Jadi alhamdulillah sekolah tersebut boleh berubah dan mendapat sekolah yang berjaya.

TBI5 : ... Jadi kita buat persediaan, persediaan kalau ada kemungkinan..., antaranya ambik klas TOFEL, saya buat persendirian. Jadi sahaja ambil kursus-kursus itu untuk melengkapkan diri supaya kalau boleh nanti dapatlah masuk ke UKM balik.

TBI4 : Dari segi disiplin, mungkin saya lebih daripada everage oranglah, saya tak banyak buang masa. Macam di rumah tu TV pun saya tidak tengok sangat...sembang-sembang saya memang kurang.

FG2 : ... Di samping itu juga melalui pengalaman-pengalaman dan pembacaan tokoh-tokoh yang telah berjaya. Berkongsi pengalaman dengan orang-orang yang telah melalui pengalaman tersebut. Jadi belajar daripada kejayaan yang telah diperolehi oleh orang lain.

TBI2 : ... Kesedaran itu timbul apabila kita melihat kawan-kawan kita yang sama dengan kita ini dia orang ini sudah tak ada disekolah..., mose of them ambik di PPIPM,...di situ kita macam rasa tercicir, jadi daripada situlah kita itu balik...menimbulkan kesedaran. 
FG1 : ...saya belajar melalui kesilapan yang saya lakukan. Jadi ketahanan jiwa memang adalah dari segi emosi. Di samping itu juga saya banyak aktif di dalam aktiviti sosial.

TBI3 : ... dalam hidup ini kita kena ada visionlah jangan hidup ini sekadar apa yang berlaku hari ini. Maksudnya the day to day. Jadi dalam hidup ini kita kena ada satu target, apa yang kita nak capai dalam kehidupan yang singkat ini. So bila kita ada target kita akan lebih terfokus, dan untuk nak capai target kita itu kita boleh fikirkan cara ataupun proses untuk itu.

TBI3 : ...yang mendorong saya untuk menyatakan bahawa kita buat bukan supaya kita nak dipuji orang, sebab pada saya idea ini satu amanah, jadi kalau kita simpan rugilah. Tapi kalau idea ini boleh kita manivestasikan, sebarkan, kalau orang tidak dapat manfaatpun sekurang-kurangnya kita dapat manfaatkan kerana kita berjaya merealisasikan idea kita.

\section{Pembahasan}

Keterampilan pendidik dalam aspek psikologis (kesadaran diri, regulasi diri, motivasi diri, empati dan keterampilan sosial) perlu ditingkatkan (Ashiba, 2003; Ghafar, 2000; Ginanjar, 2005; Goleman, 1995, 1999; M. I. Noriah, dan Aliza, A, 2002b; M. I. Noriah, Nor Sakinah. M, 2003; M. I. Noriah, Syed Najmuddin, S.H. dan Syafrimen, 2004; M. I. Noriah, Zuria,M, Siti Rahayah, A. dan Manisah M.A, 2003; Z. Noriah, 2003; Skovholt, 2000; Syafrimen, 2004; Syed Najmuddin, 2005; Zurinah, 2005). Dalam penelitian mendapati bahwa, pembinaan motivasi dapat diperankan pada kepemimpian yang maksimal, sehingga dapat meningkatkan rasa tanggung jawab dan konsistensi (Eyal, 2010; Leithwood, 2008). Bagaimanapun hasil penelitian ini sejalan dengan hasil yang diperoleh peneliti, bahwa dalam pembinaan motivasi harus dilakukan usaha secara maksimal, disiplin dan konsistensi. Diperkuat oleh (Finnigan, 2010; Wei, 2013), bahwa pembinaan motivasi dapat dibentuk jika dilakukan dengan komitmen yang tinggi.

Selanjutnya hasil penelitian menunjukkan bahwa salah satu komponen penting dalam pembinaan motivasi, yaitu melihat tantangan sebagai peluang dan amanah serta memiliki tujuan yang jelas. Menurut (Eyal, 2010) dan (Mansfield, 2012) dalam pembinaan motivasi sangat diperlukan kompleksitas yang dapat memberikan wawasan bagi pendidik untuk meningkatkan motivasi. Sedangkan (Neumerski, 2013) menjelaskan bahwa pembinaan motivasi dapat dilakukan dari sistem yang akuntabilitas. Akuntabilitas dapat peneliti dikaitkan dengan amanah, pendidik yang memiliki amanah yang tinggi tentu memiliki motivasi yang tinggi dalam mengajar. Motivasi tersebut termasuk termasuk ketekunan dalam menyelesaikan tugas-tugas, peningkatan kinerja akademik, kreativitas, dan kesejahteraan emosional (Lisa White-McNulty \& Evanthia N. Patrikakou, 2005). Motivasi pendidik dapat ditingkatkan ketika pendidik disediakan dengan alat yang akan memungkinkan mereka untuk melakukan pekerjaan yang berkualitas tinggi dalam pendidikan, dan merasa bahwa mereka memiliki tujuan atau misi pendidikan (Leithwood, 2008).

Selain itu, berdasarkan hasil penelitian pembinaan motivasi dapat dilakukan dengan belajar dari keberhasilan orang lain, dan belajar dari kegagalan diri sendiri. Covey memaparkan berbagai kisah dalam bukunya Living The 7 Habitts tentang kejayaan orang-orang yang belajar daripada pengalaman (Covey, 1990). Seseorang yang memiliki dorongan prestasi yang tinggi selalu berkeinginan untuk memenuhi kebutuhan hidupnya, lebih bersemangat untuk memotivasi diirinya ketika melihat keberhasilan orang lain (Desa, 2006). Temuan ini sejalan dengan pandangan (Mennin, 2007), bahwa seseorang yang belajar daripada pengalaman yang pernah mereka lalui, maka hidupnya akan lebih bermakna, karena terdapat berbagai pengetahuan yang tersirat di sebalik pengalaman tersebut. Motivasi dalam pendidikan merupakan kunci penghubung pada keberhasilan akademis (Anderson, 1997; Dornyei, 2001; Gardner, 2007; Gasco, 2014; Kim, 2010; Plenty, 2013; Waege, 2009). Diperkuat oleh (Davidson, 2007), bahwa motivasi pendidik diidentifikasi sebagai kunci yang telah terbukti mempengaruhi kualitas pendidikan di Tanzania. 
Penelitian lain menunjukkan bahwa motivasi pendidik dipengaruhi oleh tingkat komitmen, efektivitas, perilaku dalam organisasi dan partisipasi dalam pengembangan profesional (Morgan, 2007). Selain itu, kurangnya percaya diri (Watt, 2008), perbedaan antara gaya belajar siswa serta strategi pengajaran (O’Brien, 2012), persepsi siswa terhadap pendidik (Berson, 2015; Eyal, 2010), dan tuntutan yang dalam pelaksanaan reformasi di sekolah dapat mempengaruhi motivasi pendidik (Arar, 2013). Selain itu, (Crookes, 1997) menemukan bahwa motivasi pendidik dipengaruhi oleh pilihan kurikulum dan buku, serta kemampuan mereka untuk berpartisipasi dalam pengambilan keputusan mengenai siswa mereka sendiri. Karena pendidik memainkan peran penting dalam meningkatkan atau melemahkan motivasi belajar siswa (Assor Bernaus, 2008; Dornyei, 2007; Dweck, 2002; Kaplan, 2005; Lai, 2013; Loima, 2014; Niemiec, 2009; Urhahne, 2015). Dengan demikian, sememangnya pembinaan motivasi dapat dilakukan melalui belajar dari keberhasilan orang lain, belajar dari kegagalan diri sendiri.

Penelitian (Ozgungor, 2008) menunjukkan bahwa calon pendidik masih memiliki sikap negatif dalam mengajar sehingga siswa meremehkan profesi mereka sebagai pendidik, dengan demikian motivasi calon pendidik menjadi menurun. Sedangkan pada penelitian (Kontas, 2016) bahwa pendidik sangat termotivasi untuk bekerja lebih rajin bekerja dan akan memiliki sikap positif terhadap pengajaran profesi, sehingga terlibat baik dalam mengajar, yang pada akhirnya akan meningkatkan kualitas pendidikan. Sememangnya motivasi berprestasi, kecerdasan emosional, dan kompetensi yang tidak terpenuhi akan menyebabkan kinerja pendidik menurun (Erni R. Dewia, 2016). Fakta menunjukkan bahwa guru tidak memiliki motivasi untuk berprestasi berdasarkan penilaian diri dan penilaian dari orang lain (Erni R. Dewia, 2016). Kinerja guru akan meningkat apabila motivasi berprestasi terpenuhi (Queen, 2010). Pada penelitian (Farida, 2014) berpendapat bahwa guru sulit untuk meningkatkan kinerja mereka jika mereka memiliki motivasi yang rendah. Motivasi berprestasi berpengaruh positif dan signifikan terhadap kinerja (Lorenzo, 2012; Osvaldo, 2011; Robert, 2010). Diperkuat pada teori EQ (emotional quotient), bahwa kecerdasan emosional adalah kualitas emosional seseorang dimana orang tersebut adalah cerdas dalam memahami kesadaran diri, dapat mengatur diri mereka sendiri, memotivasi dirinya sendiri, memiliki empati dan keterampilan (D. Goleman, 2012).

Motivasi pendidik sangat penting untuk diteliti, hal tersebut karena kompleksitas motivasi pendidik dapat memberikan wawasan ke dalam bagaimana meningkatkan motivasi pendidik secara lebih luas (Caroline Mansfield 2012). Langkah-langkah yang dikembangkan untuk meningkatkan motivasi pendidik didasarkan pada tiga teori motivasi dan produktivitas, yaitu 1. Teori Harapan. Individu lebih mungkin untuk berusaha dalam pekerjaan mereka jika ada reward diantisipasi yang mereka nilai, seperti bonus atau promosi. 2. Teori Ekuitas. Individu tidak puas jika mereka diberlakukan tidak adil atas kompensasi usaha mereka dalam prestasi. 3. teori tugas pengayaan. Pekerja lebih produktif ketika pekerjaan mereka bervariasi dan menantang (Johnson, 2006). Demikian, hal ini mungkin bias dijadikan sebagai refrensi kedepan untuk meningkatkan motivasi bagi para pendidik maupun calon-calon pendidik, sehingga dapat meningkatkan kualitas pendidikan.

\section{Kesimpulan}

Menjadi seorang pendidik tidaklah mudah, banyak faktor yang perlu diperhatikan dalam mengemban tugas, amanah, dan tanggung jawab demi mensukseskan tujuan pendidikan. Untuk menjadi seorang pendidik yang profesional, tentu harus dibentuk dari proses saat di meja kuliyah (calon pendidik). Justeru seorang pendidik harus tekun, gigih, terarah serta memiliki motivasi yang tinggi dalam mencapai tujuan tersebut. Motivasi pendidik sangat diperlukan dalam pendidikan, karena tanpa motivasi pendidikan tidak akan terarah dan berjalan secara maksimal.

\section{References}

Anderson, E. S., \& Keith, T. Z. (1997). A longitudinal test of a model of academic success for atrisk high school students. Journal of Educational Research, 90, 259-268. doi: 10.1080/00220671.1997.10544582. 
Antoniou, A. S. (2000). Sources of stress and profesional burnout of teachers of special education needs in greece. Paper presented at the Kertas kerja yang dibentangkan di International Special Education Congress, University of Manchester.

Arar, K., T. Shapira, F. Azaize, and R. Hertz-Lazarowitz. (2013). Arab Women into Leadership and Management. New York: Palgrave Mcmilan.

Ashiba, W. (2003). Kecerdasan emosi di kalangan guru sekolah menenga berasrama penuh dan sekolah harian. Kertas projek Sarjana. Universiti Kebangsaan Malaysia.

Ashiba, W. (2004). Kecerdasan emosi di kalangan guru sekolah berasrama penuh dan sekolah harian, Kertas projek Sarjana.

Assor Bernaus, M., \& Gardner, R. (2008). Teacher motivational strategies, student perceptions, student motivation, and English achievement. The Modern Language Journal, 92(3), 387-401.

Berson, Y., R. Da'as, and D. Waldman. (2015). How Do Leaders and Their Teams Bring about Organizational Learning and Outcomes? Personnel Psychology, 68(1), 79-108.

Bogler, R. (2001). The Influence of Leadership Style on Teacher Job Satisfaction. Educational Administration Quarterly, 37(5), 662-683.

Budden, J. (2009). Motivation - The Teacher.

Caroline Mansfield , M. W. S. B. (2012). Goals for teaching: Towards a framework for examining motivation of graduating teachers. Australian Journal of Educational \& Developmental Psychology, 12(2012), 21-34.

Chen, J. J. (2008). Grade-level differences: Relations of parental, teacher, and peer support to academic engagement and achievement among Hong Kong students. School Psychology International, 29, 183-198. doi: 10.1177/0143034308090059

Claudia, V. (2014). The role of motivation in the development of school teachers 'career. Procedia - Social and Behavioral Sciences, 180(2014), 1109 - 1115. doi: 10.1016/j.sbspro.2015.02.220

Covey, S. R. (1990). The 7 habits of highly effective people. New York: A Fireside Book.

Creswell, J. W. (2007). Research design: qualitative and quantitave approaches. Thousand Oaks: SAGE Publication.

Creswell, J. W. (2014). Research design: qualitative and quantitave approaches. Thausand Oaks: SAGE Publication.

Creswell, J. W. (2015). Research design: qualitative and quantitave approaches. Thousand Oaks: SAGE Publication.

Crookes, G. (1997). What influences what and how second and foreign language teachers teach? Modern Language Journal, 81, 67-79.

Davidson, E. (2007). The pivotal role of teacher motivation in Tanzanian education. The Educational Forum, 71, 157-166.

Desa, A. (2006). Persekitaran keluarga dan motivasi pencapain pelajar. Dlm Rohany Nasir \& Fatimah Omar. (pnyt.). Kesejahteraan manusia perspektif psikologi. Bangi: Universiti Kebangsaan Malaysia.

Dornyei, Z. (2001). Teaching and researching motivation. Essex, England: Pearson Education Limited.

Dornyei, Z. (2007). Creating a motivating classroom environment. In J. Cummins, \& C. Davison (Eds.). International handbook of English language teaching, New York, NY: Springer, 2, 719-731.

Dulewicz, V. a. H., M. (2000). Emotional intelligence: a review and evaluation study. Journal of Managerial Psychology, 15(4), $341-372$.

Dulewicz, V. H., M. (2004). Can emotional intelligence be developed? Journal of Human Ressource management, 15, 95-111.

Dweck, C. S. (2002). Messages that motivate: How praise molds students' beliefs, motivation, and performance (in Surprising Ways). In A. Joshua (Ed.) Improving academic achievement: Impact of psychological factors on education. New York, NY: Academic Press. 38-58.

Study Report on Teacher Competency and Development Guideline on Changing Jurisdiction (2010a). 
Study Report on the Analysis of Educational Development Process of Schools after First Round of Educational Assessment (2010b).

Study Report on the Research and Development on Teacher Professional Development (2010c).

Erdem, A. R., \& Gözel, E. (2014a). Sınıf öğretmeni adaylarının öğretmenlik mesleğine ilişkin motivasyon düzeyleri. Akademik Sosyal Araştırmalar Dergisi, 21(1), 49-60. Erdem, A. R., \& Gözel, E. (2014b). Sınıf öğretmeni adaylarının öğretmenlik mesleğine ilişkin motivasyon düzeyleri. Akademik Sosyal Araştırmalar Dergisi, 2(1), 49-60.

Erni R. Dewia, P. B., and Suradi Tahmira. (2016). The influence of the antecedent variable on the teachers' performance through achievement motivation in senior high school. International Journal Of Environmental and Education, 11(9), 3161-3166. doi:10.12973/ijese.2016.912a.

Eyal, O., and G. Roth. (2010). Principal's Leadership and Teachers' Motivation: Selfdetermination Theory Analysis, Paper presented at the American Educational Research Association.

Farida. (2014). Manajemen Sumber Daya Manusia: Aplikasi Teori. Jakarta: Penerbit Elex Media Komputindo.

Finnigan, K. (2010). Principal Leadership and Teacher Motivation under High-stakes Accountability Policies. Leadership and Policy in Schools, 9, 161-189.

Gardner, R. (2007). Motivation and second language acquisition. Porta Linguarum, 8, 9-20.

Gasco, J., Goñi, A., \& Villarroel, J. D. (2014). Sex differences in mathematics motivation in 8th and 9th grade. Procedia-Social and Behavioral Sciences, 116, 1026-1031. doi: 2014.01 .340

Ghafar, M. N. (2000). Kestabilan emosi guru: perbandingan antara pensyarah dan pelajar. Jurnal Teknologi, 32(E), 1-10.

Ginanjar, A. A. (2005). Rahasia sukses membangun kecerdasan emosional dan spiritual (ESQ); the ESQ way 165. New Edition. Jakarta: Arga.

Goleman. (1995). Emotional intelligence: Why it can matter more than IQ. New York: Bantam Books.

Goleman. (1999). Working with emotional intelligence. New York: Bantam Books.

Goleman. (2001). Emotional intelligence: issues in paradigm building. Dlm. Cherniss, C. \& Goleman, D. (pnyt.). The emotionally intelligent workplace. San Francisco: Jossey-Bass.

Goleman, D. (2012). Working With Emotional Intelligence. Jakarta: PT Gramedia Pustaka Utama.

Hopkins, D. (2012). What We Have Learned from School Improvement about Taking Educational Reform to Scale. In School Effectiveness and Improvement Research, Policy and Practice, edited by C. Chapman, P. Armstrong, A. Harris, D. Muijs, D. Reynolds, and P. Sammons, . London: Routledge.

Ibrahim, M. S. (2002). Etika perkhidmatan guru.

İlter, İ. (2013). Sosyal bilgiler öğretiminde 5E öğrenme döngüsü modelinin öğrenci başarısına, bilimsel sorgulayıcı-araştırma becerilerine, akademik motivasyona ve öğrenme sürecine etkileri (Yayımlanmamış doktoratezi). Atatürk Üniversitesi Eğitim Bilimleri Enstitüsü, Erzurum.

Johnson, S. (2006). Contraints on Development and Change to Science Teacher's Practice in Egyptian Classrooms. Journal of Education for Teaching, 26(1), 9-24.

Kaplan, H., Kanat-Maymon, Y., \& Roth, G. (2005). Directly controlling teacher behaviors as predictors of poor motivation and engagement in girls and boys: The role of anger and anxiety. Learning and Instruction, 15, 397-413.

Kim, J. I., Schallert, D. L., \& Kim, M. (2010). An integrative cultural view of achievement motivation: Parental and classroom predictors of children's goal orientations when learning mathematics in Korea. Journal of Educational Psychology, 102(2), 418-437.

Kontas, H. (2016). The Effect of an Education-Themed Movie on the Academic Motivation of Teacher Candidates and Their Attitude towards Teaching Profession. Journal of Education and Training Studies, 4(6). doi: 10.11114/jets.v4i6.1483 Lai, H. T., \& Ting, K. (2013). 
English language learners' perception on motivational changes. English Language Teaching, 6(8), 10-20.

Leithwood, K., A. Harris, and D. Hopkins. 2008. (2008). Seven Strong Claims about Successful School Leadership. School Leadership and Management, 28(1), 27-42.

Lisa White-McNulty \& Evanthia N. Patrikakou, R. P. W. (2005). Fostering Children's Motivation to Learn. Partnerships.

Loima, J., \& Vibulphol, J. (2014). Internal interest or external performing? A Qualitative study on motivation and learning of 9th graders in Thailand basic education. Journal of Education and Learning, 3(3), 194-203.

Lorenzo, M. (2012). Managing EQ by Human Resource. Boston: Toronto Little, Brown and Company.

Mansfield, C. F., S. Beltman, and M. Wosnitza. (2012). Goals for Teaching: A Goal Content Approach to Understanding Motivation of Graduating Teachers. Australian Journal of Educational and Developmental Psychology, 12, 21-34.

Massry-Herzllah, K. H. A. A. (2016). Motivation to teach: the case of Arab teachers in Israel. Educational Studies, 42(1), 19-35. doi: 10.1080/03055698.2015.1127136.

Mennin, D., \& Farach, F. (2007). Emotion and evolving treatments for adult psychopathology. Clinical Psychology: Science and Practice, 14, 329-352.

Mitchell, T. R. (1997). Research in Organizational Behavior. Greenwich, CT: JAI Press.

Morgan, M., K. Kitching, and M. O'Leary. (2007). The Psychic Rewards of Teaching: Examining Global, National and Local Influences on Teacher Motivation. Paper presented at the Paper presented at the Annual Meeting of the American Educational Research Association, Chicago, IL.

Neumerski, C. (2013). Rethinking Instructional Leadership, a Review: What Do We Know about Principal, Teacher, and Coach Instructional Leadership, and Where Should We Go from Here? Educational Administration Quarterly, 49(2), 310-347.

Niemiec, C. P., \& Ryan, R. M. (2009). Autonomy, competence, and relatedness in the classroom: Applying self-determination theory to educational practice. Theory and Research in Education, 7(2), 133-144.

Nir, A., and L. Hameiri. (2014). School Principals' Leadership Style and School Outcomes: The Mediating Effect of Powerbase Utilization. Journal of Education Administration, 52(2), 2010-2227.

Noriah, M. I., dan Aliza, A. (2002a). Kecenderungan menghadapi tekanan dan implikasinya terhadap kesihatan mental guru-guru. Paper presented at the Prosiding seminar kebangsaan profession pergurun 2002, Bangi: Fakulti Pendidikan Universiti Kebangsaan Malaysia.

Noriah, M. I., dan Aliza, A. (2002b). Kecenderungan menghadapi tekanan dan implikasinya terhadap kesihatan mental guru-guru. Paper presented at the Prosiding seminar kebangsaan profession pergurun 2002, Bangi: Fakulti Pendidikan Universiti Kebangsaan Malaysia.

Noriah, M. I., Nor Sakinah. M. (2003). Pola pertautan guru- pelajar dan komitmen terhadap profesyen perguruan di kalangan guru-guru pelatih. VirTEC Journal, 3(1).

Noriah, M. I., Syed Najmuddin, S.H. dan Syafrimen. (2004). Guru dan kepintaran emosi: Implikasi ke atas kebolehan guru dalam menangani masalah sosial pelajar. Paper presented at the Prosiding seminar kebangsaan ke-3 psikologi dan masyarakat, Bangi: Pusat penerbitan dan teknologi pendidikan Universiti Kebangsaan Malaysia.

Noriah, M. I., Zuria,M, Siti Rahayah, A. dan Manisah M.A. (2003). Hubungan antara Tanggungjawab Kepada Diri, Pelajaran, Pelajar dan Masyarakat di Kalangan Guruguru. Paper presented at the Prosiding seminar kebangsaan profession pergurun 2003, Bangi: Fakulti Pendidikan Universiti Kebangsaan Malaysia.

Noriah, Z. (2003). Kepintaran Emosi di Kalangan Pekerja di Malaysia. Paper presented at the Prosiding IRPA- RMK-8 Kategori EAR.

O’Brien, J. (2012). The Potential of Continuing Professional Development: Evaluation and Impact. In School Effectiveness and Improvement Research, Policy and Practice, edited by C. Chapman, P. 
Armstrong, A. Harris, D. Muijs, D. Reynolds, and P. Sammons, 149-162. London: Routledge.

Osvaldo, R. (2011). Human Resource Management in Strength Quality Prospective. New York: Published McGraw Hill.

Ozgungor, S., \& Kapıkıran, S. (2008). Güzel sanatlar eğitimi öğrencilerinin öğretmenlik meslek bilgisi derslerine ilişkin motivasyon ve başarı düzeyleri. Pamukkale Üniversitesi Ĕ̈itim Fakültesi Dergisi, 1(23), 47-60.

Plenty, S., \& Heubeck, B. G. (2013). A multidimensional analysis of changes in mathematics motivation and engagement during high school. Educational Psychology, 33(1), 14-30. doi: 2012.740199

Queen, W. (2010). Performance Management in Organization. Revision Edition. Boston: Mas Hougton Mifflin Company.

Rich, Y., and Z. Shiram. (2010). Perceptions of Motivation among School Counselors and Teachers. The Journal of Educational Research, 98(6), $366-375$.

Robbins, S. P. J., Timothy A. (2008). Perilaku Organisasi Buku 1. Jakarta: Salemba Empat.

Robert, S. (2010). Managing Organizations, Readings and Cases. Boston: Toronto Little, Brown and Company.

Rohaty, M. (2002). Identiti guru; Isu cabaran dan halatuju. Kertas Kerja Prosiding Seminar Profesion perguruan, Selangor: Fakulti Pendidikan Universiti Kebangsaan Malaysia.

Roussel, P. (2000). La Motivation au Travail—Concept et Theories. Notes du Laboratoire Interdisciplinaire de recherché sur les Ressources Humaines et l'Emploi (LIRHE),Note No. 326. Toulouse: LIRHE.

Sani, M. (2001). Perkembangan profesionalis guru: satu tuntutan dan satu kemestian, Kertas kerja dalam seminar Nasional 10 pengurusan dan kepimpinan pendidikan. Sarojn Pasathang, K. T. P. S. (2016). Teachers' Performance Motivation System in Thai Primary Schools. International Education Studies, 9(7). doi: 10.5539/ies.v9n7p119 Schater, D. (2011). PSYCHOLOGY. United States of America: Catherine Woods.

Seebaluck, A. K., and T. D. Seegum. (2013). Motivation among Public Primary School Teachers in Mauritius. International Journal of Educational Management, 27(4), 446-464.

Skovholt, T. D. R., V. (2000). Portraits of outstanding and inadequate teachers in Singapore: The impact of emotional intelligence. Teaching and Learning, 21(1), 9-17.

Syafrimen. (2004). Profil kecerdasan emosi guru-guru sekolah menengah Zon Tengan Semenanjung Malaysia. Kertas Projek Sarjana. Universiti Kebangsaan Malaysia.

Syed Najmuddin, S. H. (2005). Hubungan antara faktor kecerdasan emosi,nilai kerja dan prestasi kerja di kalangan guru Maktab Rendah Sains Mara. Tesis Doktor Falsafah. Universiti Kebangsaan malaysia.

Umaña-Taylor, E. C. A. a. A. J. (2015). The Longitudinal Relation Between Academic Support and Latino Adolescents' Academic Motivation. Hispanic Journal of Behavioral Sciences, 1-23. doi: 10.1177/0739986315586565.

Urhahne, D. (2015). Teacher behavior as a mediator of the relationship between teacher judgment and students' motivation and emotion. Teaching and Teacher Education, 45, 73-82.

Waege, K. (2009). Motivation for learning mathematics in terms of needs and goals. 84-93.

Watt, H. M. G., and Paul W. Richardson. (2008). Motivations, Perceptions, and Aspirations concerning Teaching as a Career for Different Types of Beginning Teachers. Learning and Instruction, 18, 408-428.

Wei, Y. E. (2013). Using Multilevel Structural Equation Models to Examine Personal and School Effect on Teacher Motivation. Paper presented at the Paper presented at the Annual Meeting of American Education Research Association, San Fransisco, CA, April 27th-May 1st.

Wiersma, W. (2000). Research methods in education: an introduction. Needham Heights: Allyn and Bacon.

Yin, R. K. (1993). Applications of case study research. 
Yin, R. K. (2008). Case Study Research: Design and Method (Applied Social Research Methods). Illinois: Sage Publications, Inc.

Yin, R. K. (2013). Applications of case study research. Newbury Park: SAGE Publications.

Zurinah, I. (2005). Profil kepintaran emosi dalam kalangan guru pelatih. Paper presented at the Kertas kerja yang dibentangkan dalam Seminar Pendidikan Khas, Universiti Kebangsaan Malaysia, Bangi. 